le portiQue Le Portique

le portiQue Revue de philosophie et de sciences humaines

1 | 1998

La modernité

\title{
Architecture des contemplatifs
}

\section{(2) OpenEdition \\ 12 Journals}

Édition électronique

URL : http://journals.openedition.org/leportique/518

DOI : $10.4000 /$ leportique.518

ISSN : $1777-5280$

Éditeur

Association "Les Amis du Portique"

Édition imprimée

Date de publication : 1 janvier 1998

ISSN : 1283-8594

Référence électronique

«Architecture des contemplatifs », Le Portique [En ligne], 1 | 1998, mis en ligne le 07 juin 2005,

consulté le 25 mars 2021. URL : http://journals.openedition.org/leportique/518 ; DOI : https://doi.org/

10.4000/leportique.518

Ce document a été généré automatiquement le 25 mars 2021.

Tous droits réservés 


\section{Architecture des contemplatifs}

1 Architecture des contemplatifs. - Il serait nécessaire de comprendre un jour, et probablement ce jour est-il proche, ce qui manque avant tout à nos grandes villes : des lieux de silence, spacieux et forts étendus, destinés à la méditation, pourvus de hautes et de longues galeries pour les intempéries ou le trop ardent soleil, où ne pénètre nulle rumeur de voitures ni de crieurs, et où une bienséance plus subtile interdirait même au prêtre l'oraison à voix haute : des édifices et des jardins qui dans leur ensemble exprimeraient la sublimité de la réflexion et de la vie à l'écart ! Les temps sont révolus où l'Église possédait le monopole de la méditation, où la vita contemplativa était toujours en premier lieu vita religiosa : et tout ce que l'Église a construit dans ce genre exprime cette pensée. Je ne saurais dire comment nous pourrions bien nous satisfaire de ses édifices même désaffectés de leur destination ecclésiale : ces édifices parlent un langage beaucoup trop pathétique et contraint en tant que maisons de Dieu et en tant que lieux somptueux d'un commerce avec l'au-delà pour que nous autres sans-dieu puissions y penser nos propres pensées. Notre désir serait de nous voir nous-mêmes traduits dans la pierre et dans la plante, de nous promener au-dedans de nous-mêmes, lorsque nous irions de-ci de-là dans ces galeries et dans ces jardins.

2 Nietzsche, Le Gai Savoir, § 280. trad. Pierre Klossowski. 